Volume 5 | No. 1 | January - June 2018

\title{
The Role of Visual Merchandising in Impulse Buying Behavior: An exploration from the lens of young adult consumers
}

\author{
Hafsa Waseem ${ }^{1}$, Sobia Sultana ${ }^{1 *}$
}

\begin{abstract}
The study was conducted to identify the relationship between young adult consumer's impulse buying behavior and visual merchandising. Five techniques of visual merchandising which are window display, store layout, lighting, promotional signage and brand name was considered in the study to determine the effect. A convenient sampling technique was used to gather data. The young adult consumer's including male and female ( $N=290$, age range between 16 to 35 years) was considered for data gathering. To study the variables, questionnaire is adapted from different author's (Rook \& Fisher, 1995),(Bhalla \& Anuraag, 2010),(Wanninayake \& Randiwela, 2007),(Dua \& Karolia, 2008),(Bhatti \& Latif, 2014). Stepwise regression showed that five dimensions of visual merchandising window display, store lay out, lighting, promotional signage and brand name effect young adults consumers' impulse buying behavior directly. Findings also indicate that Visual merchandising has turned out to be an essential variable nowadays to attract consumers and to increase sales.
\end{abstract}

Keywords: Visual merchandising, Impulse buying behavior, window display, store layout, lighting, promotion signage, shop brand name.

JEL Classification: M3, M31, M37.

\section{Introduction}

All businessmen and traders are trying to equip themselves with modernization, improvement, differentiation and innovation at any cost due to red ocean rivalry in the markets and to distinguish themselves from competitors. They want to get big share in the markets and to increase their profits, but it is only possible by using different store atmospheric elements and its components (Bhatti \& Latif, 2014). According to (Smith \& Murphy, 2012)differentiation become tough for retailers grounded in marketing mix such as price, product, place and promotion. So, visual merchandising has become more operative for differentiation. In stores, lighting, color and window display are different elements that have direct effects on consumer's impulse buying behavior.

${ }^{1}$ Lahore College for Women University, Lahore, Pakistan

* Corresponding Author: sobia.hassan@1cwu.edu.pk 
The visual merchandising is an activity which promotes sale of merchandise particularly by its presentation in an outlet (Shagal, Shagal, \& Sharma, 2016). Visual merchandising fundamentally defined as everything that a consumer sees (interior and the exterior factors), creates optimistic picture of a product in the mind of a consumer and creates desire, attention, interest, and finally action on consumer's part (BastowShoop, Zetocha, \& Passewitz, 1991). Therefore, store atmosphere which includes light, music, color, and display plays a very critical role to enhance the consumer's shopping experience.

Impulse buying is a quick, powerful and a complex purchase behavior of consumer. According to (Rook, 1987), the impulsive buying is a constant feature of consumer's behavior and a vital thing for the market strategic plans.

Hefer and Cant (2013) states that every retailer wants that their outlets should be striking enough to attract the consumers and offer those products that are the demand of the customers and motivate them to make plan for impulsive purchase. To make public familiarize with their brands, the advertisers use millions of moneys every year. If visual merchandising does not have this effect desired by the consumer, the question arises whether there is any value for the shopkeepers to spend their time as well as money on the visual merchandising techniques. According to (Karbasivar \& Yarahmadi, 2011) the shopping environment in a store is a very essential determinant of impulsive buying behavior for consumer. It is composed of variables which are micro and are explicit to shopping situation and limited to a geographic space. Now a day, merchandisers are continuously working on how they can grab the attention of the end customers to make an increasingly impulsive purchase. Companies continuously working on the atmosphere of their outlets effectively for this purpose and, they carry out survey and researches' on how can they control the behaviors of the consumer for their brands. To be successful it is essential for retailer to have an ability to create different ideas and to be aware of what is happening in the industry to keep them updated.

The aim of this study is to find out how visual merchandising influences impulse buying behavior of young consumers and to determine those factors that have most impact on young adult consumer buying behavior. The key objective of this study is to find out the effect of Window display, Store layout, Lighting, Promotional signage and brand name on young adult consumer's impulse buying behavior. This study was being designed to add more to the previous research, regarding effect of visual merchandising on consumer's behavior and help the retailers who want to increase their profit by attracting more and more consumers through visual merchandising.

\section{Literature Review}

Now a day, retailers are facing intense competitive environment in the markets. They are facing many difficulties to discriminate their outlets from their competitors. In the past, they may discriminate themselves based on price, people, products, place and promotions. In the extant literature many outlets fundamentals like colors, product display, store layout, brand name and lighting have direct and immediate effects on the 
buying decision of consumers. Many researchers inquire on this topic and find out that visual merchandising has direct effect on consumer behavior. This study aims to find out effect of visual merchandising on young adult consumer behavior and how some fundamentals of visual merchandising effect behavior?

\subsection{Visual Merchandising}

Visual merchandising (VM) is defined as "presentation of goods in an effective manner, which influences customers' buying behavior" (Walters \& White, 1987).Visual merchandising means providing right product to right consumer and of course at right time. Visual merchandising is an activity which promotes sale of merchandise particularly by their presentation in an outlet (Shagal et al., 2016).So, everything that a consumer sees, whether external or internal, influences impulse buying behavior of consumers. Retailers have realized now that consumer's satisfaction and convenience are more important than just selling the products (Quartier, Vanrie, \& Van Cleempoel, 2009).

Different definitions about visual merchandising are proposed by many researchers. Kerfoot, Davies, and Ward (2003) describe it as an action by which commoditie's choice coordinates with helpful products presentation. (Ebster \& Garaus, 2011) describe visual merchandising as a science as well as an art of products presentation, which visually engaged customers. Diamond and Diamond (2004) said that visual merchandising can be described as the unique presentations of any outlet and its different products in such ways, that intended to magnetize the interest of the consumers, and encourage them making a purchase. The visual merchandising involves, how products are visually commune to shopper and whether the message that must be communicated is interpreted correctly (Wanninayake \& Randiwela, 2007). Bhalla and Anuraag (2010) stated that the process of visual merchandising is habitually known as "silent sales person" because it provides consumers information through different visual channels like lighting, product display, store layout, etc.

In an effective visual merchandising store, both exterior and interior factors are included. Display of products in windows is one of the important elements of visual merchandising because it creates first impression and image in to the consumer's mind who entered in the store. The arrangement of products on its optimum is called window display. Window display can be defined as a glamour, a glow, a point, a liveliness as well as a spark that environs an outlet and make the customers stop, come across and buy (Jain, Sharma, \& Narwal, 2012). Chandon, Hutchinson, Bradlow, and Young (2009) explained that retailers neglect lot of the arrangement of their windows when they decorate and design their outlets. Creative floor covering, backdrops and fittings influence the window display to attract customers. Successful stores windows are being changed frequently based on seasonal change, new arrivals, customers demand (Shagal et al., 2016). 
Floor layout is another name of store layout which influences consumer behavior. As, (Davies \& Tilley, 2004) comprehend that how various segments, sub sections as well as corridor of an outlet are structured with essential and uncomplicated idea of getting customers for the longer time and promote them to buy additional. According to (McGoldrick, 2002), the layout that forces the consumer to select a specific way throughout the store, maximize consumers association with products as they pass through every corridor is called Forced pattern layout. It also boosts the chances of unintended buying among consumers.

Some store elements like colors as well as lightning are included in the techniques of visual merchandising. Many researchers studied the psychological and physiological effects of colors and conclude that temperate colors like red will increase the blood pressure and high respiratory rate (Gajanayake, Gajanayake, \& Surangi, 2011).Rook (1987) state that the bright lights in the stores could increase the chance of impulse buying. In addition, it is suggested that the soft lights can bring customer in shop to inspect products. In contrast, (Areni \& Kim, 1994) found that bright lights tigers browsing product in an outlet but not in particular, affects the sales intensity. So, consumers hold and look at items more below the bright lights than soft lights (McGoldrick, 2002).Shagal et al. (2016) stated that proper lights increase the sales of merchandise by up to $20 \%$.

Varela, Ares, Giménez, and Gámbaro (2010) defines brand as an agreement, a contract or a promise with the maker of product and is a symbol of quality. According to (Keller \& Aaker, 1998) brand is an important element of visual merchandising and it is communicated to consumers through advertisement. Krutulyte, Costa, and Grunert (2009) said that the brand name is generally more powerful than packaging.

Promotional signage can be words that can be used alone as well as in the combination with the displays to express product and to notify the promotional information to consumers to encourage purchasing. Effectual promotion signage may be helpful for sellers to boost their products sales and their profit margin. Different researchers accept the significance and effects of advertisement and promotional signage on unintentional buying. There is enormous impact of advertisement on the amount of impulse purchase (Ali \& Hasnu, 2013). The different fundamentals that are used to measure the straight effect on consumer's decisions are low price, sales promotions, discounts and price cutback (Thaler, 1985),(Tendai \& Crispen, 2009).

\subsection{Consumer's Impulse Buying Behavior}

Plenty of human activities are obsessed by impulses, that are psychologically and biochemically motivated. Wide-ranging research have been started in 1950's on impulse buying consumer behavior and wanted to explore the decisions about purchase that is made by the consumers after stepping into the store environment. Researchers states that an unintended purchase are impulse buying. The description was normally operationalized as "difference among consumers total buying at the end of shopping 
and those purchases which were scheduled or the intentional buying earlier to enter in the store". Various studies investigate the consistency of unintentional buying across the various categories of a product in the different environments (Clover, 1950),(Applebaum, 1951). The purchase that is done without lot of thinking is called 'Impulse buying behavior'. One convincing and broad explanation of 'psychological impulse' is a powerful or at times irresistible need or an abrupt liking to act without thought (Goldenson, 1984). Impulse buying is knowingly not planned, but immediately takes place with a firm motivation (Wolman, 1973).According to (Rook, 1987) it is done without evaluation of different things such as need, low cost, price, etc.

Jain et al. (2012) considered the impact of VM on consumer impulse behavior and found that it has powerful influence on buying behavior of customer. Shelf presentation has also affected the impulse buying behavior of consumers. There is natural trend in consumers to focus and observe those items which are located at eye level. So, displays can increase the unplanned purchase in a store.

It is inferred from the literature that window display, product display, promotional signage, store layout, lighting, brand name are significant dimensions to be researched in visual merchandising. If visual merchandising dimensions are applied correctly and productively, the sales of store can increase hugely. Market researchers have an immense curiosity in this field, but a lot of questions regarding impulse purchase behavior, remain unreciprocated.

\section{Theoretical Framework}

Following framework was designed based on extensive literature review:
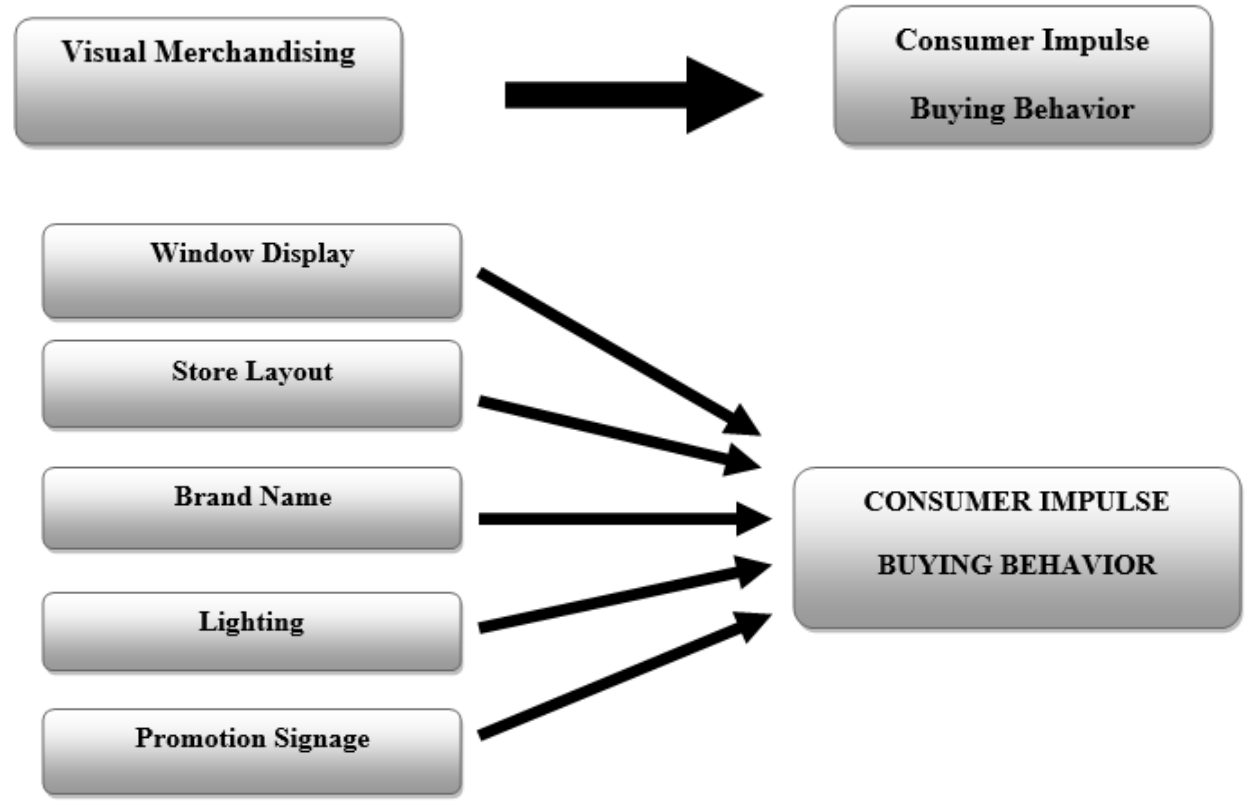


\subsection{Research Hypotheses}

To study the relationship, between Visual merchandising and the consumer impulse buying behavior, five hypotheses are developed after reviewing the literature:

H1: Consumers who do impulse buying are significantly influenced by Window Display.

$\mathrm{H}$ 2: Consumers who do impulse buying are significantly influenced by store layout.

H3: Consumers who do impulse buying are significantly influenced by Lighting.

H4: Consumers who do impulse buying are significantly influenced by Promotional Signage.

H5: Consumers who do impulse buying are significantly influenced by Brand Name.

\section{Research Methodology}

The aim of the study was to determine the effects of selected visual merchandising techniques upon the consumers' impulse behavior. So, this study uses an explanatory research to respond the stated research hypothesis. Quantitative research method was employed. To test the proposed hypotheses, a self-administered questionnaire was adapted using a five-point Likert scale from 300 respondents of the universities and colleges of Lahore. The questionnaire was adapted from different author's (Rook \& Fisher, 1995),(Wanninayake \& Randiwela, 2007),(Dua \& Karolia, 2008),(Bhatti \& Latif, 2014). The reliability of the questionnaire was check through Cronbach's alpha. The value of Cronbach's alpha was 0.78 . Hence, the questionnaire reliability was confirmed.

Convenience sampling was used to collect the responses from sample in this study. It is a non-probability sampling in which data is collected from the respondents who are easily available (Marshall, 1996). One more motive of using convenience sampling was that the actual size of the population was not known i.e., young adult consumers. For analysis, this study focuses only on the young adult consumers in LAHORE city between the ages of 16 to 35 . The key motivation to choose this age group was, people under age of 35 were pressured by the high trend of impulsive buying. The youngsters show more impulsiveness than the middle adult people, who are expected to control their desires and to be soothers to make unprompted buying (Ghani \& Jan, 2010).

In this study, the software SPSS (Statistical packages for social sciences) version 21 was used for the analysis. To analyze the collected data, the statistical methods used include; Descriptive statistics, Pearson correlation and regression analysis to understand the effect of visual merchandising on young adult consumer's impulse buying behavior.

\section{Data Analysis and Findings 5.1. Demographic Analysis}

The analysis demonstrates that among the 290 respondents $21.4 \%$ are males and $78.6 \%$ are females. Age analysis shows that most of the respondents comprise between the age of 15 to 25 they are $95.9 \%$. Only $4.1 \%$ are between the age of 26 to 35. Material status 
shows that $97.9 \%$ respondents are single, while only $2.1 \%$ are married. Education analysis shows that $4.1 \%$ respondent's education level is intermediate, $79.3 \%$ respondent's education level is bachelor's and $16.6 \%$ respondent's education level is master's and above. Job status shows that $8.3 \%$ respondents are employed while $89 \%$ are unemployed and only $2.8 \%$ are part time employeis.

\subsection{Descriptive statistics}

The descriptive statistics show that the mean value for the dependent variable (Impulse Buying Consumer Behavior) was 3.81 and standard deviation was .103. Similarly, mean and standard deviation for independent variable (window display) was 4.12 and .159 respectively. Mean and standard deviation of store layout was 3.68 and .153, lighting was 4.03 and .133, promotional signage was 4.12 and .165 and for Brand name was 4.13 and .146.

Table 1: Pearson Correlation

\begin{tabular}{|c|c|c|c|c|c|c|c|}
\hline & & $\begin{array}{c}\text { Impulse } \\
\text { Buying } \\
\text { Consumer } \\
\text { Behavior }\end{array}$ & $\begin{array}{l}\text { Window } \\
\text { Display }\end{array}$ & $\begin{array}{c}\text { Store } \\
\text { Layout }\end{array}$ & Lighting & $\begin{array}{c}\text { Promotional } \\
\text { signage }\end{array}$ & $\begin{array}{l}\text { Brand } \\
\text { Name }\end{array}$ \\
\hline \multirow{5}{*}{$\begin{array}{l}\text { Impulse } \\
\text { Buying } \\
\text { Consumer } \\
\text { Behavior }\end{array}$} & Pearson & 1 & & & & & \\
\hline & Correlation & & & & & & \\
\hline & Sig. (2- & & & & & & \\
\hline & tailed) & & & & & & \\
\hline & $\mathrm{N}$ & 290 & & & & & \\
\hline \multirow{4}{*}{$\begin{array}{l}\text { Window } \\
\text { Display }\end{array}$} & Pearson & $.687 * *$ & 1 & & & & \\
\hline & Correlation & & & & & & \\
\hline & $\begin{array}{l}\text { Sig. (2- } \\
\text { tailed) }\end{array}$ & .000 & & & & & \\
\hline & $\mathrm{N}$ & 290 & 290 & & & & \\
\hline \multirow{4}{*}{$\begin{array}{c}\text { Store } \\
\text { Layout }\end{array}$} & Pearson & $.688 * *$ & $.216^{* *}$ & 1 & & & \\
\hline & Correlation & & & & & & \\
\hline & $\begin{array}{l}\text { Sig. (2- } \\
\text { tailed) }\end{array}$ & .000 & .000 & & & & \\
\hline & $\mathrm{N}$ & 290 & 290 & 290 & & & \\
\hline \multirow[t]{3}{*}{ Lighting } & Pearson & $.626 * *$ & $.432 * *$ & $.429 * *$ & 1 & & \\
\hline & $\begin{array}{l}\text { Correlation } \\
\text { Sig. (2- } \\
\text { tailed) }\end{array}$ & .000 & .000 & .000 & & & \\
\hline & $\mathrm{N}$ & 290 & 290 & 290 & 290 & & \\
\hline
\end{tabular}


Waseem H. et al. / The Role of Visual Merchandising in Impulse Buying Behavior: An exploration from the lens of young adult consumers

\begin{tabular}{|c|c|c|c|c|c|c|c|}
\hline \multirow{3}{*}{$\begin{array}{l}\text { Promotional } \\
\text { signage }\end{array}$} & Pearson & $.596 * *$ & $.890 * *$ & $.195 * *$ & $.479 * *$ & 1 & \\
\hline & $\begin{array}{l}\text { Correlation } \\
\text { Sig. (2- } \\
\text { tailed) }\end{array}$ & .000 & .000 & .001 & .000 & & \\
\hline & $\mathrm{N}$ & 290 & 290 & 290 & 290 & 290 & \\
\hline \multirow{3}{*}{$\begin{array}{l}\text { Brand } \\
\text { Name }\end{array}$} & $\begin{array}{l}\text { Pearson } \\
\text { Correlation }\end{array}$ & $.673 * *$ & $.666^{* *}$ & $.327 * *$ & $.160 * *$ & $.490 * *$ & 1 \\
\hline & $\begin{array}{l}\text { Sig. (2- } \\
\text { tailed) }\end{array}$ & .000 & .000 & .000 & .006 & .000 & \\
\hline & $\mathrm{N}$ & 290 & 290 & 290 & 290 & 290 & 290 \\
\hline
\end{tabular}

According to the given table, there exist a positive relationship between the dependent variable which is young adult consumers impulse buying behavior and the independent variable visual merchandising (window display, store layout, Lighting, promotional signage, Brand name). At 0.01 levels (2-tailed) correlation of all variables is significant. Pearson Correlation (r) shows Consumer's impulse buying behavior and Window display have significant Positive relationship ( $r=.687, \mathrm{n}=290$, $\mathrm{p}$-value $<0.01$ ). Similarly, Store Layout have significant Positive relationship ( $r=.688 n=290$, $p$-value $<0.01)$. Lighting has significant Positive relationship $(\mathrm{r}=.626, \mathrm{n}=290$, $\mathrm{p}$-value $<0.01)$. Promotional signage has significant Positive relationship $(r=.596 \mathrm{n}=290$, $\mathrm{p}$-value < 0.01). Similarly, Brand Name has significant Positive relationship $(r=.673, n=290, p-$ value $<0.01)$

\subsection{Regression Analysis}

Table 2: ANOVA

\begin{tabular}{cccc}
\hline Model & Mean Square & $F$ & Sig. \\
\hline Regression & 2.405 & 1007.691 & $.000^{\mathrm{a}}$ \\
Residual & .002 & & \\
\hline
\end{tabular}

The independent variable Visual Merchandising has significant impact on dependent variable Young adult consumers' behavior as verified by $\mathrm{p}$ value which is 0.000 (shown in ANOVA table). $\mathrm{F}=1007.61$, ( $\mathrm{p}$-value $=0.000<0.05$ ). So, there exists sufficient evidence to conclude that an independent variable is helpful for calculating the influence on young consumer behavior of Lahore, Pakistan. Consequently, the model is useful and fit. 
Waseem H. et al. / The Role of Visual Merchandising in Impulse Buying Behavior: An exploration from the lens of young

Table 3: Model summary

(Impulse consumer buying behavior and Visual Merchandising)

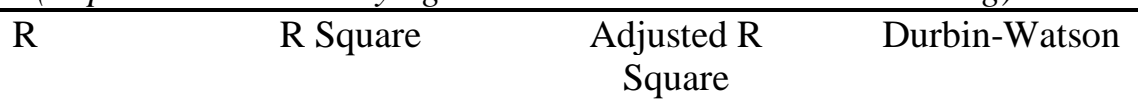

.882

.778

.777

1.959

Coefficients (Impulse consumer buying behavior and Visual Merchandising)

Un standardized Standardized

Co

Coefficients Coefficients

linearity

statistics

\begin{tabular}{llllll}
\hline$B$ & Std. & Beta & $t$ & Sig. & VIF
\end{tabular}

(Constant)

Error

Visual

.545

.103

$.814 \quad .026$

5.288

31.744

1.000

Merchandising

The Independent variable (Visual Merchandising) has a significant effect on dependent variable (Consumer's impulse buying behavior) as p-value $=0.000$ i.e. $<0.05$. Similarly, positive $(B=.814 ; p$-value $<0.05)$ shows positive relationship between Visual merchandising and Consumer's impulse buying behavior. The value of $r=.882$ which lies between 0 and 1 represents strong relation between Visual merchandising and young consumer impulse buying behavior. According to the above mentioned model summary, the value of $R^{2}$ is 0.778 . It represents that $77 \%$ of variance in dependent variable i.e. Consumer's impulse buying behavior is due to our independent variable i.e. Visual Merchandising and remaining $23 \%$ is due to those factors which are note taken in this study. So $R^{2}$ represents that $77 \%$ of the model is defined by included variables, whereas there exist some other factors or variables which are also significant and affect Consumer behavior.

Table 4: Model summary (Impulse consumer buying behavior and Window display, Store layout, Lighting, Promotional signage, Brand name)

\begin{tabular}{|c|c|c|c|c|}
\hline & $R$ & R Square & $\begin{array}{l}\text { Adjusted R } \\
\text { Square }\end{array}$ & $\begin{array}{l}\text { Durbin- } \\
\text { Watson }\end{array}$ \\
\hline $\begin{array}{l}\text { Window } \\
\text { Display }\end{array}$ & .687 & .472 & .470 & 1.811 \\
\hline Store Layout & .688 & .473 & .471 & 1.590 \\
\hline Lighting & .626 & .391 & .389 & 1.652 \\
\hline $\begin{array}{l}\text { Promotional } \\
\text { Signage }\end{array}$ & .596 & .356 & .353 & 1.728 \\
\hline Brand Name & .673 & .452 & .451 & 1.983 \\
\hline
\end{tabular}

Sukkur IBA Journal of Management and Business - SIJMB | Volume 5 No. 1 January - June 2018 @ Sukkur IBA University 
Waseem H. et al. / The Role of Visual Merchandising in Impulse Buying Behavior: An exploration from the lens of young adult consumers

Table 5: Coefficients (Impulse consumer buying behavior and Window Display, Store layout, Lighting, Promotional signage, Brand name)

$\begin{array}{cc}\begin{array}{c}\text { Un standardized } \\ \text { Coefficients }\end{array} & \begin{array}{c}\text { Standardized } \\ \text { Coefficients }\end{array}\end{array}$

\begin{tabular}{|c|c|c|c|c|c|}
\hline & $\boldsymbol{B}$ & $\begin{array}{l}\text { Std. } \\
\text { Error }\end{array}$ & Beta & $T$ & Sig. \\
\hline (Constant) & 1.968 & .115 & & 17.104 & .000 \\
\hline $\begin{array}{l}\text { Window } \\
\text { Display }\end{array}$ & .448 & .028 & .687 & 16.051 & .000 \\
\hline (Constant) & 2.102 & .107 & & 19.725 & .000 \\
\hline $\begin{array}{c}\text { Store } \\
\text { Layout }\end{array}$ & .466 & .029 & .688 & 16.075 & .000 \\
\hline (Constant) & 1.859 & .144 & & 12.923 & .000 \\
\hline Lighting & .485 & .036 & .626 & 13.605 & .000 \\
\hline (Constant) & 2.277 & .122 & & 18.652 & .000 \\
\hline $\begin{array}{c}\text { Promotional } \\
\text { Signage }\end{array}$ & .373 & .030 & .596 & 12.607 & .000 \\
\hline (Constant) & 1.841 & .128 & & 14.388 & .000 \\
\hline $\begin{array}{l}\text { Brand } \\
\text { Name }\end{array}$ & 477 & .031 & .673 & 15.428 & .000 \\
\hline
\end{tabular}

The Independent variables (Window Display, Store Layout, Lighting, Promotional Signage and Brand Name) has a significant effect on dependent variable (Consumer's impulse buying behavior) accordingly as: $P$-value $=0.000$ i.e. $<0.05$. Similarly, a positive $(B=.448 ; \mathrm{p}$-value $<0.05), P$-value $=0.000$ i.e. $<0.05$. Similarly, a positive $(B$ $=.466 ; p$-value $<0.05), P$-value $=0.000$ i.e. $<0.05$. Similarly, a positive $(B=.485 ; p$ value $<0.05), P$-value $=0.000$ i.e. $<0.05$. Similarly, a positive $(B=.373$; $p$-value < $0.05), P$-value $=0.000$ i.e. $<0.05$. Similarly, a positive $(B=.477$; $\mathrm{p}$-value $<0.05)$ shows positive relationship between Consumer's impulse buying behavior and independent variables respectively. Hence our all 5 hypotheses are accepted. 
The value of $r=.687, r=.688, r=.626, r=.596, r=.673$ which lies between 0 and 1 represents strong relationship between Consumer's impulse buying behavior and window display, Store Layout, Lighting, Promotional signage and Brand name respectively. According to the above-mentioned model summary, $R^{2}=0.472,0.473$, $0.391,0.356$ and 0.452 for window display, Store Layout, Lighting, Promotional signage and Brand name respectively. Which means $47 \%$ of variance in dependent variable i.e. Consumer's impulse buying behavior is due to our independent variable i.e. Window display and store layout. Furthermore, 37\%, 39\% and 45\% variance are due to Lighting, Promotional signage and Brand name respectively. Durbin-Watson is $1.811,1.590,1.652,1.728$, and 1.983 for each respectively that lies between 0 and 4 shows there is no autocorrelation and error terms are independent of each other.

\section{Discussion and Conclusion}

To study the relationship, between VM and the consumer's impulse buying behavior, five hypotheses are developed after reviewing the literature. There is sufficient evidence provided by the data, regarding significant relationships between selected visual merchandising techniques (window display, store layout, lighting, promotional signage, Brand name) and young consumers' impulse behavior. The details of each hypothesis are as below:

H1: Consumers who do impulse buying are significantly influenced by Window Display. Analysis of this study stated that there is direct and strong relationship between window display and the young consumers' impulse behavior. The results entail that the young consumers be likely to make impulse purchases when they saw an eye-catching Window display. This result is in accordance with the studies of (Mathew, 2008),(HUBRECHTS \& Koktürk, 2012),(Bhatti \& Latif, 2014).

H2: Consumers who do impulse buying are significantly influenced by store layout.

Analysis of the study stated that there is also direct and strong relationship between store layout and young consumers' impulse buying behavior. Because a good store layout encourages the buyers to move in a comfortable and free flow space to look around the articles, which influence young consumer to make an impulse purchase. This result is also in accordance with and supported by the studies of (McGoldrick, 2002),(Michon, Chebat, \& Turley, 2005),(Schiffman \& Kanuk, 2007),(Lee \& Kacen, 2008),(Bhatti \& Latif, 2014).

H3: Consumers who do impulse buying are significantly influenced by Lighting.

The analysis also stated that there is direct but moderate relationship between Lighting and young consumers' impulse buying behavior. Better and colorful lighted products push customers to shop, and promote purchasing. This result is also in accordance with the studies of (Areni \& Kim, 1994),(McGoldrick, 2002),(Bhalla \& Anuraag, 2010).

H4: Consumers who do impulse buying are significantly influenced by Promotional Signage. 
According to analysis of the study, there is a direct but moderate relationship between promotional signage and young consumers' impulse buying behavior. The promotional signage has a vast impact on increasing the amount of impulse buying. People buy more when they see any discount or clearance sale on products. This result is also in accordance with the studies of (Youn \& Faber, 2000), (Laroche, Pons, Zgolli, Cervellon, \& Kim, 2003),(Virvalaite, Saladiene, \& Bagdonaite, 2009),(HUBRECHTS \& Koktürk, 2012).

H5: Consumers who do impulse buying are significantly influenced by Brand Name.

Analysis of the study also stated that there is a direct and strong relationship between Brand Name and young consumers' impulse buying behavior. Because when the store does well in developing its loyal consumers, at whatever time the consumer sees that brand she or he wants to purchase it without any plan. This result is also in accordance with the studies of (Fichter \& Jonas, 2008),(Ares, Giménez, \& Deliza, 2010),(Bhatti \& Latif, 2014).

\section{Limitations and Future suggestions}

The data was only collected from the Lahore city. So, study sample was geographically limited. Moreover, the instrument was limited to the quantitative method. The qualitative research for this study might have different outcomes regarding the perception of the customers. Finally, there are numerous overlooked variables that can play moderating role and can impact the consumers' buying behavior e.g. living standards etc. It is recommended that a qualitative approach as well as a combination of both approaches is recommended for future researchers to grasp the perception of customers regarding their impulse buying behavior. Retailers and marketers point of views can also be evaluated in future researches. Furthermore, internal and external motivators of impulse buying can be added to expand the phenomenon of the impulse buying behavior.

\section{References}

Ali, A., \& Hasnu, S. (2013). An analysis of in-store shopping environment on consumers' impulse buying: Evidence from Pakistan. Retrieved on, 560-570.

Applebaum, W. (1951). Studying customer behavior in retail stores. Journal of marketing, 16(2), 172-178.

Areni, C. S., \& Kim, D. (1994). The influence of in-store lighting on consumers' examination of merchandise in a wine store. International journal of research in marketing, 11(2), 117-125.

Ares, G., Giménez, A., \& Deliza, R. (2010). Influence of three non-sensory factors on consumer choice of functional yogurts over regular ones. Food Quality and Preference, 21(4), 361-367. 
Bastow-Shoop, H. E., Zetocha, D. F., \& Passewitz, G. (1991). Visual merchandising: A guide for small retailers: North Central Regional Center for Rural Development, Iowa State University of Science and Technology.

Bhalla, S., \& Anuraag, S. (2010). Visual merchandising: Tata McGraw-Hill Education.

Bhatti, K. L., \& Latif, S. (2014). The impact of visual merchandising on consumer impulse buying behavior. Eurasian Journal of Business and Management, 2(1), 24-35.

Chandon, P., Hutchinson, J. W., Bradlow, E. T., \& Young, S. H. (2009). Does in-store marketing work? Effects of the number and position of shelf facings on brand attention and evaluation at the point of purchase. Journal of marketing, 73(6), $1-17$.

Clover, V. T. (1950). Relative importance of impulse-buying in retail stores. Journal of marketing, 15(1), 66-70.

Davies, J., \& Tilley, N. (2004). Interior design: using the management services approach in retail premises. Management Services, 48(7), 10-13.

Diamond, J., \& Diamond, E. (2004). Contemporary visual merchandising and environmental design: Pearson College Division.

Dua, S., \& Karolia, A. (2008). Visual Merchandising-'The changing scenario'. fibre2fashion. com.

Ebster, C., \& Garaus, M. (2011). Store layout and visual merchandising: New-York: Business Expert Press.

Fichter, C., \& Jonas, K. (2008). Image effects of newspapers: How brand images change consumers' product ratings. Zeitschrift für Psychologie/Journal of Psychology, $216(4), 226$.

Gajanayake, R., Gajanayake, S., \& Surangi, H. (2011). The impact of selected visual merchandising techniques on patronage intentions in supermarkets (study based on Colombo district). Paper presented at the 2nd International Conference on Business and Economic Research Proceeding.

Ghani, U., \& Jan, F. A. (2010). An exploratory study of the impulse buying behavior of urban consumers in Peshawar. Paper presented at the International Conference on Business and Economics.

Goldenson, R. M. (1984). Longman dictionary of psychology and psychiatry: AddisonWesley Longman Ltd.

Hefer, Y., \& Cant, M. C. (2013). Visual Merchandising Displays' Effect On Consumers: A Valuable Asset Or An Unnecessary Burden For Apparel Retailers. The International Business \& Economics Research Journal (Online), 12(10), 1217.

HUBRECHTS, L., \& Koktürk, B. (2012). Effects of visual merchandising on young consumers' impulse buying behaviour.

Jain, V., Sharma, A., \& Narwal, P. (2012). Impact of visual merchandising on consumer behavior towards women's apparel. International Journal of Research in Management, 5(2), 106-117. 
Waseem H. et al. / The Role of Visual Merchandising in Impulse Buying Behavior: An exploration from the lens of young

Karbasivar, A., \& Yarahmadi, H. (2011). Evaluating effective factors on consumer impulse buying behavior. Asian Journal of Business Management Studies, 2(4), 174-181.

Keller, K. L., \& Aaker, D. A. (1998). The impact of corporate marketing on a company's brand extensions. Corporate Reputation Review, 1(4), 356-378.

Kerfoot, S., Davies, B., \& Ward, P. (2003). Visual merchandising and the creation of discernible retail brands. International Journal of Retail \& Distribution Management, 31(3), 143-152.

Krutulyte, R., Costa, A. I., \& Grunert, K. G. (2009). A cross-cultural study of cereal food quality perception. Journal of Food Products Marketing, 15(3), 304-323.

Laroche, M., Pons, F., Zgolli, N., Cervellon, M.-C., \& Kim, C. (2003). A model of consumer response to two retail sales promotion techniques. Journal of Business research, 56(7), 513-522.

Lee, J. A., \& Kacen, J. J. (2008). Cultural influences on consumer satisfaction with impulse and planned purchase decisions. Journal of Business research, 61(3), 265-272.

Marshall, M. N. (1996). Sampling for qualitative research. Family practice, 13(6), 522526.

Mathew, R. (2008). Apparel Merchandising: Book Enclave.

McGoldrick, P. J. (2002). Retail marketing: McGraw-Hill.

Michon, R., Chebat, J.-C., \& Turley, L. W. (2005). Mall atmospherics: the interaction effects of the mall environment on shopping behavior. Journal of Business research, 58(5), 576-583.

Quartier, K., Vanrie, J., \& Van Cleempoel, K. (2009). The interaction between interpreted space, mood and behavior in retail environments: a conceptual research model. IASDR09 'Design: Rigor and relevance, 2-4.

Rook, D. W. (1987). The buying impulse. Journal of consumer research, 14(2), 189199.

Rook, D. W., \& Fisher, R. J. (1995). Normative influences on impulsive buying behavior. Journal of consumer research, 22(3), 305-313.

Schiffman, L., \& Kanuk, L. (2007). Purchasing behavior. Upper Saddle River, NJ: Pearson Prentice Hall.

Shagal, S., Shagal, G., \& Sharma, A. (2016). Visual merchandising: a key element in retail industry. Management, 2(2), 115-120.

Smith, N. C., \& Murphy, P. E. (2012). Marketing ethics: a review of the field: Sage: London.

Tendai, M., \& Crispen, C. (2009). In-store shopping environment and impulsive buying. African journal of marketing management, 1(4), 102-108.

Thaler, R. (1985). Mental accounting and consumer choice. Marketing science, 4(3), 199-214.

Varela, P., Ares, G., Giménez, A., \& Gámbaro, A. (2010). Influence of brand information on consumers' expectations and liking of powdered drinks in central location tests. Food Quality and Preference, 21(7), 873-880. 
Waseem H. et al. / The Role of Visual Merchandising in Impulse Buying Behavior: An exploration from the lens of young adult consumers

Virvalaite, R., Saladiene, V., \& Bagdonaite, R. (2009). Peculiarities of impulsive purchasing in the market of consumer goods. Engineering Economics, 62(2).

Walters, D., \& White, D. (1987). Retail marketing management: Springer.

Wanninayake, W., \& Randiwela, P. (2007). The impact of visual merchandising on consumer store choice decisions in Sri Lankan supermarkets. Paper presented at the 7th Global conference on Business \& Economics.

Wolman, B. B. (1973). Concerning psychology and the philosophy of science. Handbook of general psychology.

Youn, S., \& Faber, R. J. (2000). Impulse buying: its relation to personality traits and cues. ACR North American Advances. 